\title{
Amerikan Sinagoglarında Yetişkin Din Eğitimi
}

\section{Adult Religious Education in American Synagogues}

Tauber, Sarah M. Open Minds, Devoted Hearts: Portraits of Adult Religious Education (Eugene, Pickwick Publications, 2015, xvi+168). ISBN 978-149-821-876-4

\section{Mahmut Salihoğlu ${ }^{*}$}

\author{
Anahtar Kelimeler \\ Yetişkin din eğitimi, Yahudilik, Sinagog, Rabbi, Amerika \\ Keywords \\ Adult religious education, Judaism, Synagogue, Rabbi, America
}

Bilgi ve teknoloji üretiminin hızla geliştiği ve bilgi edinme kaynaklarının çeşitlendiği günümüzde yaşam boyu öğrenme modern hayatın ayrılmaz bir parçası haline gelmiştir. Çeşitli eğitim kurumları yaşam boyu eğitime yönelik programlar geliştirmenin yanı sıra sınıf ortamında gerçekleştirilen eğitimi dijital platforma taşımakta ve herkesin erişimine açmaya çalışmaktadır. Günümüzde eğitim kurumları okullar ve üniversitelerle sınırlı olmaktan çıkmıştır. İstekli kişiler çok farklı platformlarda öğrenme imkanları bulmaktadır. Din eğitimi de bu genel durumdan farklı değildir. Yetişkinlerin dini konuları öğrenmesi için ibadethaneler ve orada hizmet veren din görevlileri önemli bir işlev görmektedir. Bireyler ibadetlerini yerine getirdikleri mabetlerde aynı zamanda din ile ilgili öğrenimlerine devam etme imkanı bulmaktadır.

Jewish Theological Seminary of America'da ders veren Sarah M. Tauber tarafindan kaleme alınan Open Minds, Devoted Hearts: Portraits of Adult Religious Education (Açık Zihinler, Adanmış Gönüller: Yetişkin Din Eğitiminden Portreler), Amerika'da sinagoglarda din eğitimi veren Yahudi din adamlarını konu edinmektedir. Yazarın doktora araştırmasına dayanan kitap din adamlarını, yetişkinlere din eğitimi hizmeti sunan öğreticiler olma açısından

\footnotetext{
* Sorumlu Yazar: Mahmut Salihoğlu (Doç. Dr.), İstanbul Üniversitesi, İlahiyat Fakültesi, Felsefe ve Din Bilimleri Bölümü, İstanbul, Türkiye. E-posta: mahmut.salihoglu@istanbul.edu.tr ORCID: 0000-0003-2379-3712

Attf: Salihoglu, M. “Amerikan Sinagoglarında Yetişkin Din Eğitimi." Sarah M. Tauber'in "Open Minds, Devoted Hearts: Portraits of Adult Religious Education" adlı eserinin değerlendirmesi. darulfunun ilahiyat 32, 2 (2021). Advanced online publication.

https://doi.org/10.26650/di.2021.32.2.1001750
} 
farklı boyutlarıyla ele almaktadır. Manevi arayışın dini ibadet ve uygulamaların önüne geçtiği bir kültürde kişi manevi rehberlik için neden din adamına başvurur sorusu çalışmanın çıkış noktasını oluşturmaktadır.

Kitap okuyucuyu, yetişkin eğitimi (andrology) teorilerinden, farklı sinagoglarda görevli üç rabbinin uygulamalarına, oradan da sinagogtaki yetişkin din eğitiminde rabbilerin farklı fonksiyonlarının teorileştirilmesine doğru bir yolculuğa çıkartmaktadır.

Yazar yarı yapılandırılmış sorularla gerçekleştirdiği yüz yüze görüşmelere dayalı niceliksel araştırmasını portreleştirme yöntemiyle okuyucuya sunmaktadır. Araştırmaya katılan kişilerin anonimliğini korumak amacıyla kitapta portreleri sunulan rabbiler ve görev yaptıkları sinagoglar gerçek isimleri ile anılmamış, onun yerine şahıslara ve kurumlara temsili isimler verilmiştir. Jonathan Fisk, Rina Lewin ve Eric Miller olarak isimleri verilen rabbilerden Rina kadın, diğer ikisi erkektir. Portreleri sunulan üç rabbiden ikisinin yani Jonathan ve Rina'nın hizmet verdiği sinagogun Reform Yahudiliğine mensup olduğu açıkça belirtilmiştir. Eric'in sinagogunun ideolojik mensubiyeti açikça ifade edilmese de Ortodoks olmadığ kesinlikle anlaşılmaktadır. Yazar üçüncü sinagogun Muhafazakar Yahudiliğe mensup olduğunu dolaylı olarak ifade etmektedir. (s. 120)

Kitabı oluşturan sekiz bölüm dört ana başlık altında değerlendirilebilir.

1. Yetişkin eğitiminde mevcut teorilerin ele alındığı birinci bölümün başlığı "Temel Teoriler ve Yeni Gelişmeler" (Foundational Theories and New Advances) şeklindedir.

2. Konu edilen rabbilerin detaylıca tanıtıldığı üç, dört ve beşinci bölümlerin başlıkları "Bahçıvan" (The Gardener), "Ebe" (The Midwife) ve "Öğrenen" (The Learner) olarak belirlenmiştir. Bu başlıklar altında sırasıyla Jonathan Fisk, Rina Lewin ve Eric Miller ile yapılan görüşmeler ve yazarın gözlemleri kaydedilmiştir. Her üç başlığın altında önce ilgili rabbi tanıtılmış, sonra sinagogta din eğitimine bakışı, verdiği dersler, uyguladığı yöntemler, derslerinde öne çıkan temalar sunulmuştur. Böylece okuyucu hem rabbinin yetiştiği şartları ve dini formasyonunu öğrenmekte hem de onun din eğitimi ile ilgili teorik görüşleri ve pratik uygulamaları hakkında bilgi sahibi olmaktadir.

3. Yazar adı geçen din adamları ile yaptığı görüşmelere dayanarak sinagogta yetişkin din eğitiminde rabbilerin öne çıkan üç işlevini ve bunların çeşitli boyutlarını beş, altı ve yedinci bölümde sunmaktadır. Bölüm başılıları sırasıyla şöyle belirlenmiştir: "Kolaylaştırıcı" (Facilitator), "Birlikte öğrenen" (Colearner) ve "Toplum kurucu" (Community builder). Yazar her üç rabbi ile 
yaptığ1 görüşmelerde öne çıkan hususlardan bir kuram üreterek sinagogta verilen din eğitiminde Yahudi din adamının rolünün boyutlarını belirlemeye çalışmaktadır.

4. "Günümüz İçin Din Görevlisi" (A Clergy for Our Time) olarak belirlenen sekizinci başlıkta ise araştırmanın bir değerlendirmesi yapılmakta ve günümüzde "din adamlarının toplum için hala önem arz etmekte olduğu" (s. 149) sonucuna varilmaktadir.

Yahudiliğin ideolojik ve pratik açıdan yeniliğe açık Reform ve Muhafazakar ekollerinin temsilcilerinin görüşleri üzerine kurulan bu araştırma geleneksel Yahudi yorumuna bağlı olan din adamlarının görüşlerini yansıtmamaktadır. Özellikle Amerika'da gün geçtikçe etkisi daha çok hissedilen Hasidi Yahudiliğe mensup rabbilerin de yetişkin din eğitimi ile yakından ilgilendikleri ve bunun için özel olarak çaba sarf ettikleri bilinmektedir. Bu açıdan çalışma, konunun belli bir ideolojiyi paylaşan bir kesim tarafından nasıl görüldüğünü yansıtmaktadır. Benzer bir araştırmanın geleneksel Yahudi yorumuna bağlı din adamları arasında da yapılması mevcut durumun daha gerçekçi bir fotoğrafını görmemizi sağlayacaktır.

Öte yandan kitap Türkiye' de yetişkin din eğitimi alanında ufuk açıcı çalışmalara örneklik edebilir. Türkiye'de yetişkinlere verilen din eğitiminin çeşitli boyutları hakkında çalışmalar yayınlanmaktadır. Ancak bu eğitimi veren kişilerle yapılacak görüşmelere dayalı alan araştırmalarına ihtiyaç duyulduğu da bir gerçektir. Yetişkinlere din eğitimi verenlerin kendilerini nasıl algıladıkları ve eğitim verdikleri kişilerle ilişkilerini nasıl değerlendirdikleri gerçekleştirilecek alan araştırmaları ile net bir şekilde ortaya konulabilir. Din eğitiminde uzmanlaşmış akademisyenlerin genç araştırmacıları teorik ve tarihsel konulardan çok, güncel ve uygulamaya yönelik konularda çalışma yapmaya teşvik etmeleri durumunda Türkiye'de verilen din eğitiminin toplam kalitesinin yükseleceğine şüphe yoktur. Konunun örnek bir uygulaması olarak Sarah Tauber'in eserinin Türkçeye çevrilmesi, genel okuyucunun yanı sıra özellikle yetişkin eğitimi ve yetişkinlere din eğitimi alanları ile ilgilenenlere bir tecrübeyi yansıtması açısından faydalı olacaktır. ${ }^{1}$

1 Bu kitabı yayınladıktan sonra "rabbi” ünvanı almak için eğitim gören Dr. Sarah Tauber 2020 yılında pankreas kanserinden vefat etmiştir. 
